Jurnal Algoritme

Vol. 1, No. 1, Oktober 2020, Hal. 111 - 119

\title{
Perbandingan Algoritma Backpropagation Dan Support Vector Machine Pada Pengenalan Jenis Biji Jagung
}

\author{
Yunarto ${ }^{1}$, M. Rizky Pribadi ${ }^{2}$, Hafiz Irsyad ${ }^{3}$ \\ ${ }^{1,2,3}$ STMIK Global Informatika MDP; Jl. Rajawali No. 14; (0711) 376400 \\ Program Studi Teknik Informatika, STMIK Global Informatika MDP, Palembang \\ e-mail: ${ }^{1}$ yunarto09@mhs.mdp.ac.id, ${ }^{2}$ rizky@mdp.ac.id, ${ }^{3}$ hafizirsyad@mdp.ac.id
}

\begin{abstract}
Abstrak
Jagung termasuk tumbuhan biji-bijian seperti padi, gandum, sorgum yang dikonsumsi sebagai sumber makanan pokok di Amerika dan beberapa wilayah di Indonesia seperti Madura, Nusa Tenggara Timur, Sulawesi dan Jawa Tengah. Jagung biji memiliki banyak jenis, maka dari itulah jika jagung biji tersebut tercampur akan susah untuk dibedakan. Tujuan dari penelitian ini adalah untuk mengenali biji jagung tersebut. Jenis biji jagung yang digunakan adalah jagung merah pozole, jagung pipil, jagung putih dan jagung warna-warni yang difoto menggunakan camera 16MP dengan jarak pengambilan foto $10 \mathrm{~cm}$ antara kamera dengan objek jagung. Metode pengenalan yang digunakan adalah algoritma backpropagation dan support vector machine, sedangkan untuk ekstraksi fitur menggunakan metode GLCM(Gray Cooccurence Matrix) yang terdiri dari Contrast, energy, homogeneity, dan correlation. Pada perhitungan dengan confusion matrix hasil tertinggi didapatkan pada algoritma backpropagation dengan rata-rata accuracy 97,5, rata-rata precision 95\% dan rata-rata recall sebesar 95,1\% dibandingkan dengan algoritma support vector machine yang hanya mendapat rata-rata accuracy 97,1\%, rata-rata precision 93,3\% dan rata-rata recall sebesar 95\%.
\end{abstract}

Kata kunci - jagung, pengenalan, GLCM, backpropagation, support vector machine

\begin{abstract}
Maize includes grains such as rice, wheat, sorghum which is consumed as a staple food source in America and some regions in Indonesia such as Madura, East Nusa Tenggara, Sulawesi and Central Java. Corn seeds have many types, so from that if the corn seeds are mixed it will be difficult to distinguish. The purpose of this study was to recognize the corn kernels. Types of corn kernels used are pozole red corn, pipil corn, white corn and colorful corn which are photographed using a 16MP camera with a distance of $10 \mathrm{~cm}$ photo taking between the camera and the corn object. The recognition method used is the backpropagation algorithm and support vector machine, while for feature extraction using the GLCM (Gray Co-occurrence Matrix) method which consists of Contrast, energy, homogeneity, and correlation. In the calculation with the confusion matrix the highest results obtained in the backpropagation algorithm with an average accuracy is 97.5 , an average precision is $95 \%$ and an average recall is $95.1 \%$ compared to the support vector machine algorithm which only gets an average accuracy is $97,1 \%$, an average precision is $93.3 \%$ and an average recall is $95 \%$.
\end{abstract}

Keywords - corn, recognition, GLCM, backpropagation, support vector machine.

jurnal.algoritme@mdp.ac.id 


\section{PENDAHULUAN}

J agung adalah salah satu tanaman pangan penghasil karbohidrat yang terpenting di dunia, selain gandum dan padi, Bagi penduduk Amerika Tengah dan Selatan, bulir jagung adalah pangan pokok, sebagaimana bagi sebagian penduduk Afrika dan beberapa daerah di Indonesia.

Pada masa kini, jagung juga sudah menjadi komponen penting pakan ternak. Penggunaan lainnya adalah sebagai sumber minyak pangan dan bahan dasar tepung maizena. Berbagai produk turunan hasil jagung menjadi bahan baku berbagai produk industri[1] Jagung biji memiliki banyak jenis, maka dari itulah jika jagung biji tersebut tercampur akan susah untuk dibedakan. Tujuan dari penelitian ini adalah untuk mengenali biji jagung tersebut. Ada 4 jenis jagung yang digunakan pada Penelitian ini adalah jagung merah pozole, jagung pipil, jagung putih dan jagung warna-warni.

Ada beberapa algoritma yang memiliki kemampuan untuk mengenali objek, salah satunya adalah Jaringan Syaraf Tiruan. Jaringan Saraf Tiruan adalah prosesor yang terdistribusi besar-besaran secara parallel yang dibuat dari unit proses sederhana, yang mempunyai kemampuan untuk menyimpan pengetahuan berupa pengalaman dan dapat digunakan untuk proses lain[2].

Selain backpropagation ada juga algoritma lain yang bisa digunakan untuk melakukan pengenalan yaitu Support Vector Machine. Support Vector Machine merupakan suatu teknik untuk melakukan prediksi, baik dalam kasus klasifikasi maupun regresi. Support Vector Machine berada dalam satu kelas dengan Artificial Neural network dalam hal fungsi dan kondisi permasalahan yang bisa diselesaikan[3].

Adapun beberapa penelitian terdahulu yang telah dilakukan untuk mengenenali kualitas biji jagung menggunakan metode pengenalan objek membahas tentang analisis distribusi intensitas RGB citra digital untuk klasifikasi kualitas biji jagung menggunakan JST[4]. Selain itu ada juga penelitian yang meneliti tentang klasifikasi kualitas biji jagung berdasarkan fitur ekstraksi warna (RGB) dengan menggunakan algoritma fuzzy logic[5].

Selain itu Support Vector Machine juga dapat digunakan untuk mengenali beberapa object antara lain penelitian yang melakukan pengenalan deteksi senyum yang dibagi menjadi dua kelas, yaitu kelas senyum dan kelas bukan senyum. Data yang digunakan pada Penelitian ini menggunakan dataset yang terdiri dari dua jenis citra yaitu citra senyum dan citra bukan senyum lalu di cropping. Setelah itu menggunakan ekstraksi ciri R-HOG untuk mendeteksi citra bibir dan senyum menggunakan algoritma SVM[6]. Penelitian yang berfokus tentang deteksi buah pada pohon menggunakan algoritma SVM dengan menggunakan fitur ekstraksi tekstur[7]. Ada juga penelitian yang menggunakan Support Vector Machine untuk mengenali jenis daging yaitu tentang penggunaan algoritma support vector machine untuk mengenali citra jenis daging berdasarkan tekstur menggunakan ekstraksi ciri GLCM[8]. Adapun penelitian terdahulu yang menggunakan algoritma backpropagation sebagai pengelanan objek tentang perbandingan akurasi pengenalan jenis beras dengan fitur ekstraksi GLCM dan di implementasikan menggunakan algoritma backpropagation pada beberapa resolusi kamera yaitu 5MP, $8 \mathrm{MP}, 12$ MP, 14 MP, dan 16MP. Jarak pemotretan $9 \mathrm{~cm}$. Hasil tertinggi didapatkan pada resolusi kamera $12 \mathrm{MP}[9]$.

Pada penelitian terdahulu juga ada yang telah membandingkan algoritma backpropagation dan Support Vector Machine yang menggunakan split validation tentang komparasi Support Vector Machine dan backpropagation untuk prediksi kelulusan sertifikasi benih kentang, hasil pengenalan oleh SVM lebih besar dibandingkan backpropagation[10].

Dari penelitian tentang jagung yang ada di jurnal-jurnal sebelumnya, Sudah ada yang membandingkan algoritma backpropagation dan support vector machine dengan proses validasi menggunakan split validation tetapi belum ada penelitian sebelumnya yang menggunakan K-

Yunarto et., al (Perbandingan Algoritma Backpropagation Dan Support Vector Machine Pada Pengenalan Jenis Biji Jagung) 
fold validation dengan 4 ciri fitur statistik dari GLCM dalam pengenalan jenis jagung. Maka penelitian ini penting untuk dilakukan.

\section{METODE PENELITIAN}

Metode penelitian yang digunakan pada penelitian ini dapat dilihat pada Gambar 1.

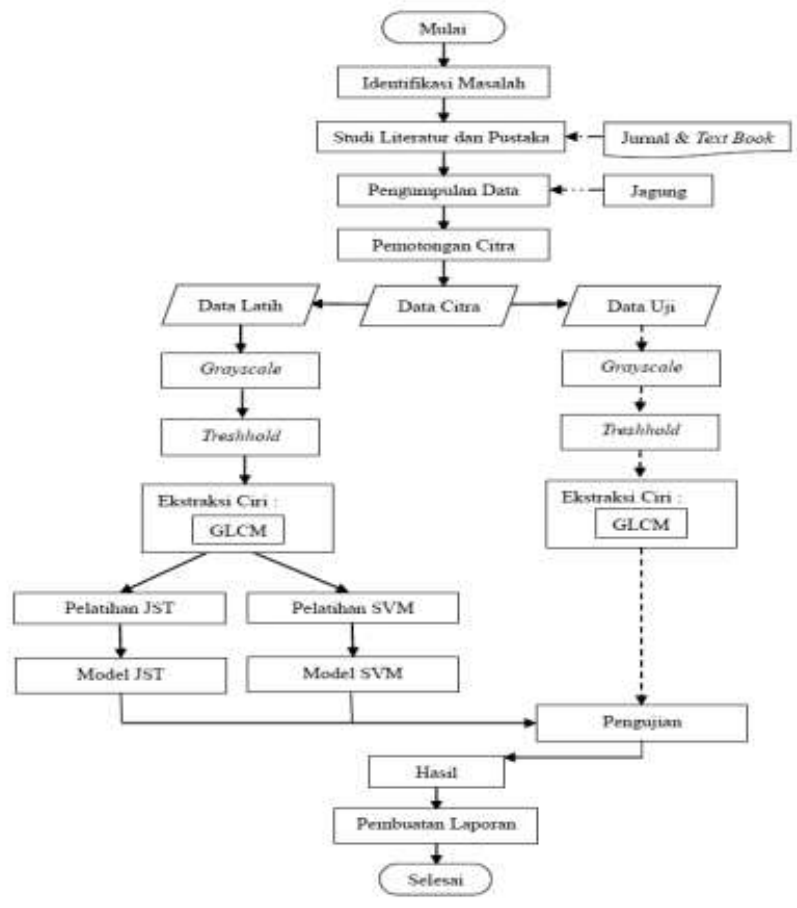

Gambar 1 Metodologi Penelitian

\subsection{Identifikasi Masalah}

Penelitian dimulai dengan melakukan pencarian topik-topik mengenai penelitian tentang pengenalan jenis jagung menggunakan jaringan saraf tiruan backpropagation. Peneliatian ini difokuskan pada perbandingan akurasi pengenalan jenis jagung menggunakan JST backpropagation dan support vector machine. Pada tahap ini digunakan metode Gray Level Co-occurance Matrix (GLCM) untuk mengambil fitur ciri dari citra. Kemudian akan dilakukan pengenalan citra jenis jagung menggunakan JST backpropagation dan support vector machine. Penelitian dilanjutkan dengan mencari jurnal, buku dan hasil penelitian yang berkaitan dengan GLCM, backpropagation dan support vector machine yang berfokus pada pengenalan jenis jagung. Tahapan ini bertujuan untuk mencari referensi literature yang relevan sehingga penelitian 


\subsection{Pengumpulan Data}

Pada tahap ini, dilakukan pengumpulan pemgambilan data citra jagung yang diambil dengan menggunakan sebuah kamera, cahaya, dan lokasi yang di sesuaikan dari 4 jenis jagung, masing-masing sebanyak 35 data latih dan 15 data uji. Contoh Gambar pada saat pengumpulan data sebelum dilakukan cropping dan treshold dapat dilihat pada Gambar 2. Kemudian gambar tersebut akan dijadikan data latih dan data uji untuk lebih jeasnya dapat dilihat pada Gambar 3.

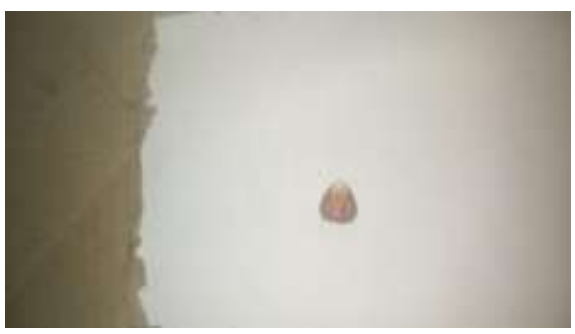

Gambar 2. Citra Jagung Merah Pozole

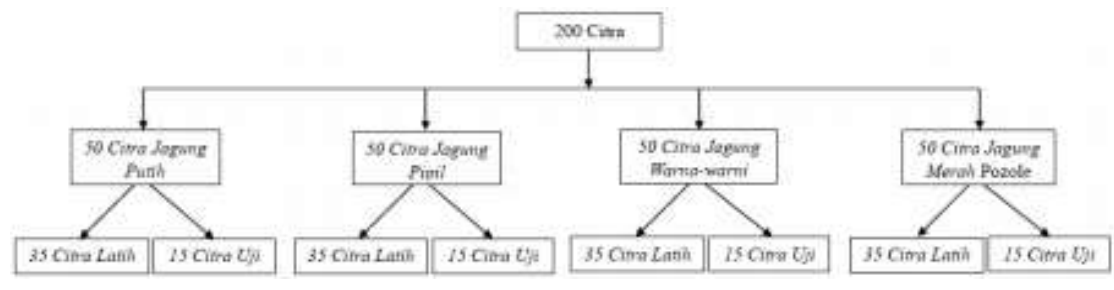

Gambar 3 Penyesuaian Data Citra

\section{3 Pemotongan Citra}

Pada tahapan ini, melakukan pemotongan terhadap citra asli yang telah diambil bertujuan untuk fokus ke objek jagungnya saja menggunakan aplikasi MATLAB dengan pisisi $(\mathrm{x}, \mathrm{y})=(588,237)$ dan ukuran pixel citra adalah $320 \times 320 \mathrm{px}$ dapat dilihat pada gambar 4 .

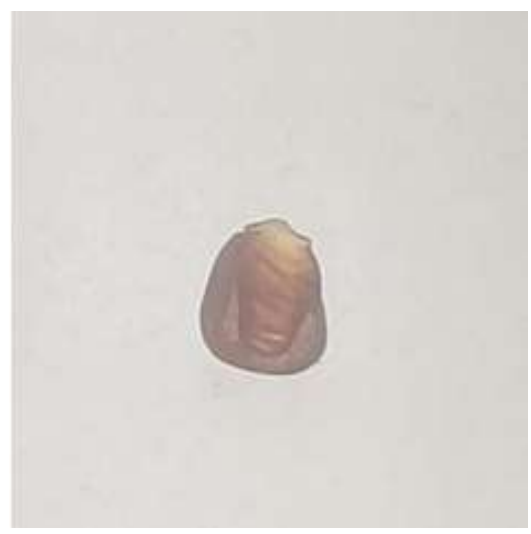

Gambar 4. Gambar 320x320 px 


\section{4. Tresholdin}

Pada tahapan ini, dilakukan pengubahan citra ke grayscale, dilakukan thresholding untuk menghilangkan informasi yang tidak dibutuhkan dari citra sehingga hanya fokus kepada citra jagungnya saja dengan menggunakan aplikasi MATLAB. Gambar setelah melalui tahapan pemotongan citra dan tresholding dapat dilihat pada Gambar 5.

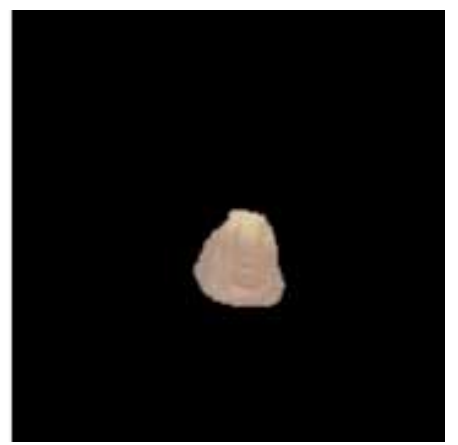

Gambar 5. Citra Akhir

\subsection{Ekstraksi Fitur}

Ekstraksi fitur adalah proses pengambilan ciri atau fitur dari dalam sebuah citra. Pada tahapan ini, akan dilakukan perhitungan terhadap citra dan dicari ciri pembedanya. Dalam proses ekstraksi ini peneliti menggunakan nilai yang didapat dari metode Gray Level Cooccurance Matrix (GLCM). GLCM merupakan metode yang digunakan untuk menentukan derajat keabuan dari sebuah citra dengan merepresentasikannya dalam sebuah matriks $\mathrm{Co}$ occurance dalam ukuran tertentu. Matriks inilah yang kemudian digunakan untuk menghitung ciri statistic orde kedua citra, yaitu Contrast, Correlation, Energy, dan Entropy.

\subsection{Pelatihan JST Backrpopagation dan Support Vector Machine}

Pada tahapan ini, dilakukan proses pelatihan dengan pada Jaringan Saraf Tiruan (JST) dan Support Vector Machine (SVM) untuk membangun sistem yang akan digunakan untuk mengenali jenis jagung menggunakan nilai yang didapatkan dari ekstraksi fitur GLCM untuk masing-masing jenis jagung yang dilatih. Setelah proses pelatihan selesai, didapatkan hasil output dari pelatihan JST dan SVM yang kemudian digunakan untuk proses pengujian pengenalan jenis jagung Adapun target yang ingin didapatkan dari data latih yang digunakan pada proses pelatihan jaringan saraf tiruan dan support vector machine sebagai output dapat dilihat pada Tabel 3.1.

Tabel 1. Target Hasil Output Pelatihan

\begin{tabular}{|l|c|c|c|c|}
\hline $\begin{array}{l}\text { Target } \\
\text { Objek }\end{array}$ & $\begin{array}{l}\text { Jagung } \\
\text { Merah } \\
\text { Pozole }\end{array}$ & Jagung Pipil & Jagung Putih & $\begin{array}{l}\text { Jagung Warna- } \\
\text { warni }\end{array}$ \\
\hline JagungMerah Pozole & 1 & 0 & 0 & 0 \\
\hline Jagung Pipil & 0 & 1 & 0 & 0 \\
\hline Jagung Putih & 0 & 0 & 1 & 0 \\
\hline $\begin{array}{l}\text { Jagung Warna- } \\
\text { warni }\end{array}$ & 0 & 0 & 0 & 1 \\
\hline
\end{tabular}

Yunarto et., al (Perbandingan Algoritma Backpropagation Dan Support Vector Machine Pada Pengenalan Jenis Biji Jagung) 


\subsection{Confusuin Matrix}

Pada tahapan ini, dilakukan pengujian pada sistem yang telah dilatih menggunakan model JST dan SVM untuk mengenali data uji untuk mengetahui tingkat akurasi pengenalan jenis jagung dengan parameter fitur tekstur dari GLCM dan kemudian dilakukan perbandingan tingkat akurasi terhadap masing-masing Algoritma. Untuk membandingkan nilai dari tingkat akurasi sistem dapat digunakan rumus confusion matrix yang dimana akan menghitung nilai precision, recall, dan accuracy. Cara perhitungan confusion matrix tersebut bisa dilihat pada Persamaan (1), (2), (3).

Recall

$$
\begin{aligned}
& =\frac{T P}{(T P+N)} * 100 \% \\
& =\frac{T P+T N}{(T P+T N+F P+F N)} * 100 \% \\
& =\frac{T P}{(T P+P)} * 100 \%
\end{aligned}
$$

Dimana accuracy merupakan seberapa akurat sistem dapat mengklasifikasikan data secara benar, precision merupakan jumlah data kategori positif yang diklasifikasikan secara benar dibagi dengan total data yang diklasifikasi positif, Recall merupakan penunjuk berapa persen data kategori positif yang terklasifikasikan dengan benar oleh sistem, True Positive (TP) merupakan jumlah data positif yang dikenali dengan benar oleh sistem, True Negative (TN) merupakan jumlah data negative yang dikenali dengan benar oleh sistem, False Negative (FN) merupakan jumlah data positif namun dikenali salah oleh sistem dan False Positive (FP) merupakan jumlah data negatif namun dikenali positif oleh sistem.

\section{HASIL DAN PEMBAHASAN}

\subsection{Hasil Pengenalan menggunakan algoritma backpropagation}

Pada Penelitian menggunakan algoritma backpropagation akan menggunakan 3 hidden laye yang terdiri dari 120 neuron pada layer 1,105 neuron pada layer 2 dan 120 pada layer 3 sebagai model JST untuk mengenali jenis biji jagung. Hasil confusion matrix dapat dilihat pada Gambar 6 .

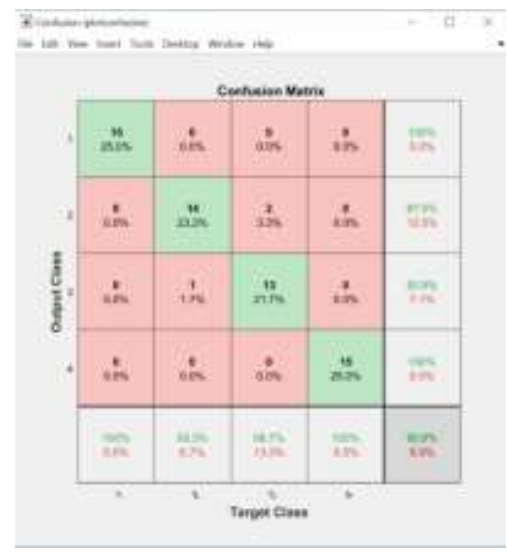

Gambar 6 Confusion matrix menggunakan JST

Hasil dari perhitungan dari confusion matrix ada proses pengujian terhadap model JST untk mengenali 4 jenis biji jagung dengan rata-rata akurasi didapatkan sebesar $97.5 \%$, rata-rata precision didapat sebesar $95.0 \%$ dan rata-rata recall didapatkan sebesar $95.1 \%$ dengan waktu 0.8825 detik.

Yunarto et., al (Perbandingan Algoritma Backpropagation Dan Support Vector Machine Pada Pengenalan Jenis Biji Jagung) 


\subsection{Hasil Pengenalan menggunakan algoritma SVM}

Pada pengujian Arsitektur SVM yang telah diperoleh terhadap data uji. Dari pengecekan tersebut didapat hasil terbaik dengan menggunakan jenis kernel Linear sebagai model SVM untuk mengenali jenis biji jagung. Hasil"confusion matrix dapat dilihat pada Gambar 7.

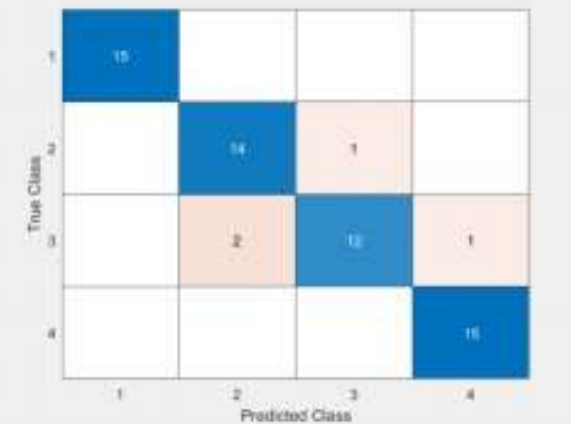

Gambar 7. Confusion matrix menggunakan SVM

hasil dari perhitungan dari confusion matrix ada proses pengujian terhadap model SVM untuk mengenali 4 jenis biji jagung dengan rata-rata akurasi didapatkan sebesar $97.1 \%$, rata rata precision didapat sebesar $93.3 \%$ dan rata-rata recall didapatkan sebesar $95.0 \%$ dengan waktu 1.6845 detik.

\subsection{Pengujian Menggunakan GUI Matlab}

Berikut ini adalah hasil pengujian pengenalan jenis biji jagung menggunakan GUI matlab R2019a dapat dilihat pada Gambar 8. dan gambar 9.

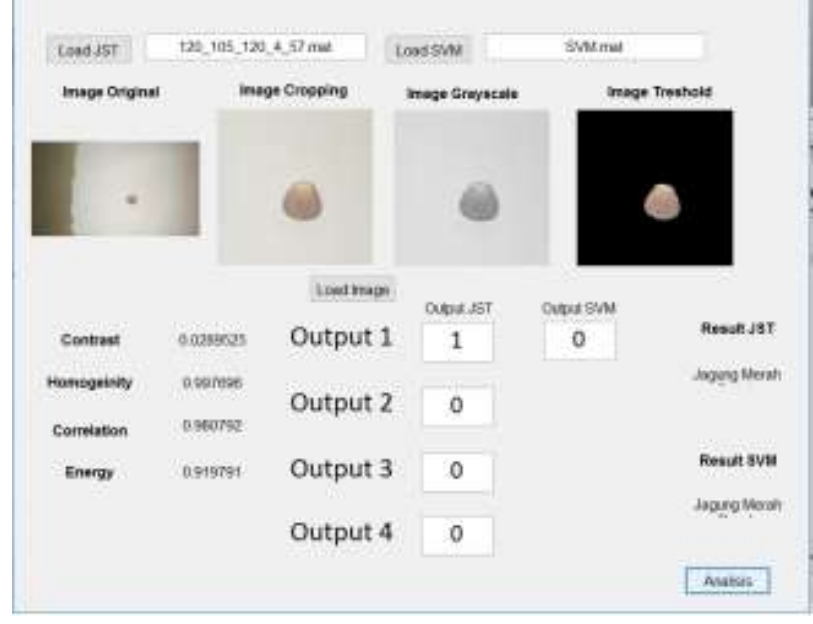

Gambar 8. Pengujian Menggunakan GUI Matlab 


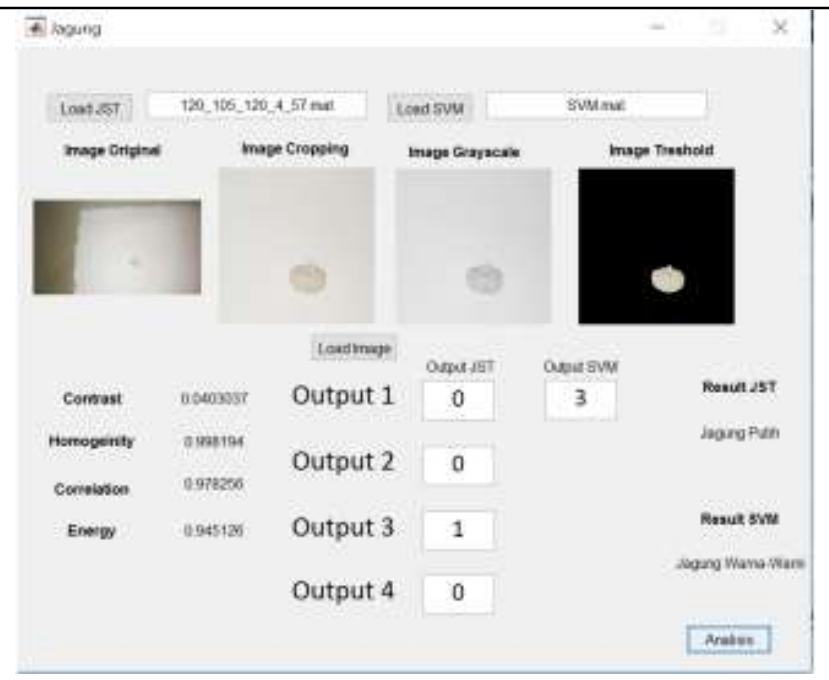

Gambar 9. Pengujian Menggunakan GUI Matlab2

Pada Gambar 8. menjelaskan algoritma backpropagation dan support vector machine dapat mengenali jenis biji jagung dengan benar yaitu jagung merah Pozole. Sedangkan pada gambar 9. menjelaskan algoritma backpropagation dapat mengenali jagung putih dengan benar tetapi pada algoritma support vector machine salah mengenali jagung putih sebagai jagung warna-warni.

\subsection{Perbandingan Algoritma Backpropagation dan SVM} Machine

Tabel 2 Perbandingan Algoritma Backpropagation dan Algoritma Support Vector

\begin{tabular}{|c|c|c|c|c|}
\hline Algoritma & Waktu Proses & Accuracy & Precision & Recall \\
\hline Backpropagation & $0.8825 \mathrm{~s}$ & $97.5 \%$ & $95 \%$ & $95.1 \%$ \\
\hline Support Vector Machine & $1.6845 \mathrm{~s}$ & $97.1 \%$ & $93.3 \%$ & $95 \%$ \\
\hline
\end{tabular}

Pada Tabel 2 menunjukkan perbandingan algoritma backpropagation dan support vector machine pada pengenalan jenis biji jagung dengan perbandingan berupa waktu proses, accuracy, precision dan recall.

\section{KESIMPULAN}

Berdasarkan hasil penelitian yang telah dilakukan dapat disimpulkan bahwa pengujian penelitian yang telah dilakukan menggunakan camera dengan resolusi 16 MP dengan jarak potret $10 \mathrm{~cm}$, citra yang didapat kemudian dipotong dengan ukuran 320x320 px menggunakan aplikasi MATLAB R2019a serta penggunaan ekstraksi ciri GLCM sebagai nilai input pada jaringan syaraf tiruan dan Support Vector Machine, dapat disimpulkan bahwa penggunaan algoritma backpropagation memperoleh hasil pengenalan yang lebih baik dengan rata-rata accuracy 97,5 , rata-rata precision $95 \%$ dan rata-rata recall sebesar $95,1 \%$ dibandingkan dengan algoritma support vector machine yang hanya mendapat rata-rata accuracy 97,1\%, rata-rata precision $93,3 \%$ dan rata-rata recall sebesar $95 \%$.

Yunarto et., al (Perbandingan Algoritma Backpropagation Dan Support Vector Machine Pada Pengenalan Jenis Biji Jagung) 
1. Pada hasil diatas menyimpulkan bahwa untuk penggunaan algoritma backpropagation pada pengenalan jenis biji jagung dengan ekstraksi GLCM lebih cocok dibandingkan dengan algoritma support vector machine.

2. Pada Tabel 2 menjelaskan waktu yang diperlukan untuk pembuatan model pada backpropagation lebih cepat dengan waktu tercepat 0.8825 detik dibandingkan dengan algoritma SVM dengan waktu tercepat 1.6845 detik.

\section{SARAN}

Saran-saran Berdasarkan kesimpulan yang telah dijelaskan, terdapat saran yang dapat digunakan untuk membantu mengembangkan penelitian selanjutnya agar mendapatkan hasil yang lebih baik yaitu:

1. Mencoba eksperimen pada beberapa fitur ekstraksi ataupun menggabungkan beberapa fitur ekstraksi yang mungkin dapat meningkatkan tingkat akurasi.

2. Menambah jumlah data latih maupun dapat uji agar algoritma memiliki banyak data sehingga berkemungkinan mendapatkan hasil yang lebih baik.

3. Membandingkan algoritma lainnya seperti algoritma KNN, LVQ dan algoritma lainnya.

\section{DAFTAR PUSTAKA}

[1] Mandiri, T. K. T., 2010. Pedoman bertanam jagung, CV. Nuansa Aulia, Bandung.

[2] Haykin, S., 2009. Nueral networks and learning machines, Vol.1, Ed.3, Pearson, United State of America.

[3] Santosa, B., 2007. Data mining teori dan aplikasi: Teknik pemanfaatan data untuk keperluan bisnis, Graha Ilmu, Yogyakarta.

[4] Bustomi, M. A., dan Dzulfikar, A. Z., 2014, Analisis distribusi intensitas rgb citra digital untuk klasifikasi kualitas biji jagung menggunakan jaringan syaraf tiruan. Jurnal Fisika Dan Aplikasinya, vol 10, hal 127-132.

[5] Munarto, R., Permata, E., dan Salsabilla, R., 2014, Klasifikasi kualitas biji jagung manis berdasarkan fitur warna menggunakan fuzzy logic, Simposium Nasional RAPI XIII - 2014 FT UMS, hal 5-12.

[6] M.Abrar, A. H., Andrie, S. M. ., Alamsyah, D., dan Devella, S., 2018, Implementasi metode HOG dan support vector machine ( SVM ) untuk multiple smile detection. STMIK Global Informatika MDP, hal 1-11.

[7] Sahertian, J., dan Sanjaya, A., 2017, Deteksi buah pada pohon menggunakan metode svm dan fitur tekstur. Semnas Teknomedia, hal19-24.

Yunarto et., al (Perbandingan Algoritma Backpropagation Dan Support Vector Machine Pada Pengenalan Jenis Biji Jagung) 
[8] Neneng, N., Adi, K., dan Isnanto, R., 2016, Support vector machine untuk klasifikasi citra jenis daging berdasarkan tekstur menggunakan ekstraksi ciri gray level cooccurrence matrices (GLCM). Jurnal Sistem Informasi Bisnis, vol 6, hal 1-10.

[9] Gasim, dan Ricardo, D., 2019, Perbandingan akurasi pengenalan jenis beras dengan algoritma, vol 1, Jurnal RESTI, hal 1-8.

[10] Suryadi, U. T., 2015, Komparasi support vector machine dan neural network untuk prediksi kelulusan sertifikasi benih kentang, seminar nasional informatika (SEMNASIF), vol 1, hal 308-314. 